
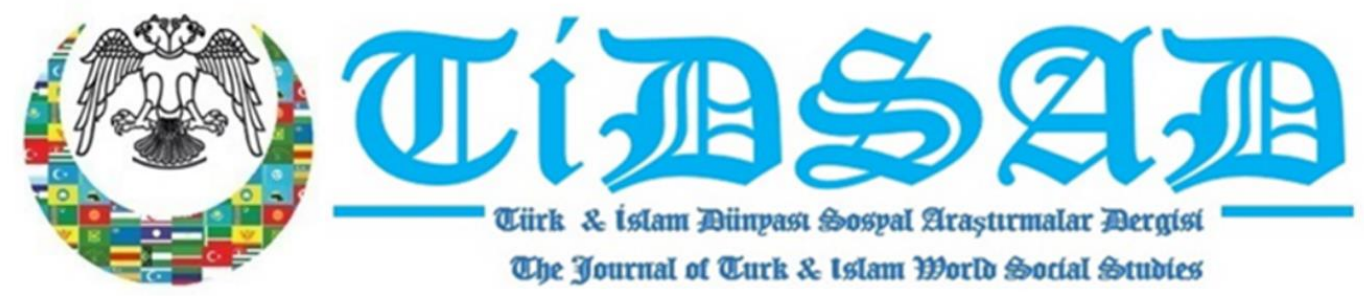

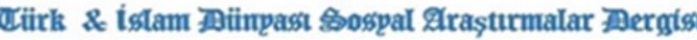

The Journal of Turk \& tstam Morlo Sotal Stưtes

\section{İbn Battûta'ya Göre XIV. Yüzyılda Altınordu Devleti'nde Kadınların Toplumdaki Saygınlığı}

According to Ibn Battuta, the Prestige of Women in Society in the Altınordu State in the XIV Century

\title{
Salih DEMİRBILLE**
}

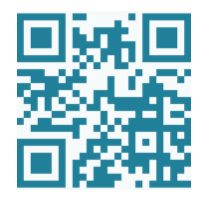

Geliş/Submitted:

12.11.2021

Kabul/Accepted:

23.12.2021

Yayın/Published:

Citation / Atıf

Demirbilek, S. (2021). İbn Battûta'ya Göre XIV. Yüzyılda Altınordu Devleti’nde Kadınların Toplumdaki Saygınlığı. Türk \& Íslam Dünyası Sosyal Araştırmalar Dergisi, 8 (31), 162-171.

Demirbilek, S. (2021). According to Ibn Battuta, the Prestige of Women in Society in the Altinordu State in the XIV Century. The Journal of Turk \& Islam World Social Studies, 8 (31), 162-171.

Makale Türü:

Araştırma Makalesi
Article Information:

\section{Research Article}

This article was checked by Intihal.net. Bu makale İntihal.net tarafından taranmıștır.

This article is under the Creative Commons license. Bu makale Creative Commons lisansı altındadır.

*Doç. Dr., Ondokuz Mayıs Üniversitesi, salihd@omu.edu.tr 

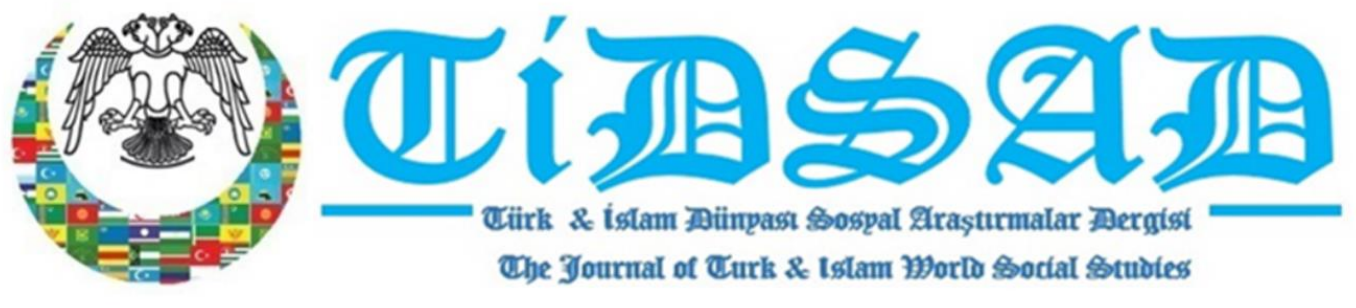

\title{
İbn Battûta'ya Göre XIV. Yüzyılda Altınordu Devleti'nde Kadınların Toplumdaki Saygınlığı 1
}

\author{
According to Ibn Battuta, the Prestige of Women in Society in the Altınordu \\ State in the XIV Century
}

\section{Doç. Dr. Salih DEMİRBILLEK}

Öz: İbn Battûta XIV. yüzyılın önemli seyyahlarından birisidir. Battûta seyahat anılarını ve gözlemlerini dünyaca ünlü Seyahatnamesinde toplamıştır. Onun eseri Türkiye'de farklı yayınevleri tarafında tam nüsha olarak yayınlanmıştır. Seyahatname kültür tarihimiz için asla ihmal edilmemesi gereken eserlerden birisidir. $\mathrm{Bu}$ çalışmada Battûta'nın Altınordu Devleti'ndeki kadınlara gösterilen saygıya dair gözlemleri konu edilmiştir. Bilindiği üzere Altınordu Devleti'nin yöneticileri Moğol asıllı ancak halkı ekseriyetle Türk idi. Battûta'nın bu gözlemleri hükümdarın eşleri tarafından ayrı ayrı kabul edilmiş ziyaretlerine dayanmaktadır. Battûta hem Anadolu'da hem de Altınordu Devleti'nde kadınlara gösterilmiş olan saygıyı diğer hiçbir millette görmediğini yazmaktadır. Onun bu iddiası kültür tarihimizde kimileri tarafınca ileri sürülen olumsuz tezlere karşı belge hükmündedir. Ayrıca onun bu iddiası eski Türk devletlerindeki kültürün XIV. Yüzyılda sürdügünü gösterir.

Anahtar Kelimeler: İbn Battûta, seyahatname, kadın, Altınordu Devleti, Özbek Han.

\begin{abstract}
Ibn Battuta He is one of the important travelers of 14th century. Battuta collected his travel memories and observations in his world-famous Travel Book. His work has been published in full copy by different publishing houses in Turkey. Travelogue is one of the works that should never be neglected for our cultural history. In this study, Battuta's observations about the respect shown to women in the Altınordu State are discussed. As it is known, the rulers of the Altınordu State were of Mongol origin but the people were mostly Turks. These observations of Battûta are based on the visits of the sovereign, which were accepted separately by his wives. Battuta writes that he has not seen the respect shown to women in both Anatolia and the Altınordu State in any other nation. This claim of his is like a document against the negative theses put forward by some in our cultural history. In addition, his claim shows that the culture in the old Turkish states continued in the 14th century.
\end{abstract}

Keywords: Ibn Batttuta, seyahatname, woman, Altınordu State, Uzbek Khan.

1 “COPE-Dergi Editörleri İçin Davranış Kuralları ve En İyi Uygulama İlkeleri” beyanları: Bu çalışma için herhangi bir çıkar çatışması bildirilmemiştir. Bu çalışma için etik kurul onayı gerekmemektedir.

Statements of "COPE-Code of Conduct and Best Practices Guidelines for Journal Editors": No conflicts of interest were reported for this article. Ethics committee approval is not required for this article. 


\section{Giriș}

Türklerde kadına saygı konusunda yapılmış çalışmaların ittifak ettikleri nokta Türklerin en eski çağlarından yana bu meziyete sahip olduklarıdır. Öyle ki Türkler devlet yönetiminde Kağanın yanı sıra Katun'un da sözünün geçtiği; Kağanın olmadığı durumlarda Katun'un yetkiyi elinde tutup devleti yönettiği bilinmektedir. Bunun son örneği de Osmanlı Devletidir.

Türklerde devlet yönetiminin dışında sosyal hayatta da kadınların saygı gördüğünün bir tanığı da İbn Battûta'dır. İbn Battûta, dünyaca ünlü eseri Seyahatnamesinde Türkler arasında kadınların saygı gördüklerini Anadolu ve özellikle Altınordu Devleti'ndeki gezileri sırasındaki gözlemlerine dayanarak söylemektedir.

Onun bu gözlemleri Türk kültür tarihi açısından önem arz etmektedir. Onun yaşadığı dönem olan XIV. yüzyıl Türk coğrafyasındaki tespitleri günümüzdeki Türk tarih ve Türk kültür tarihi açısından ileri sürülen kimi olumsuz tezlerin sorgulanmasına da yardımcı olmaktadır. Türklerde sosyal hayatta kadının rolü üzerine ileri sürülen kimi olumsuz iddialar Battûta'nın tanıklığında değiștirilebilir.

Battûta'nın diğer milletlerde de görüp karşılaştırma yaparak Türklerde sosyal hayatta kadına gösterilen saygıya başka hiçbir millette şahit olmadığına dair gözlemleri bu açıdan oldukça önemlidir. Bu çalışmada Battûta'nın Altınordu Devletinde kadına gösterilen saygiya dair tespitleri ve bu tespitlerin Türk kültür tarihindeki önemi üzerinde durulacaktir.

\section{1.İbn Battûta}

İbn Battûta² lakabıyla tanınmış olan seyyahın asıl ismi Şerefeddin Ebu Abdullah Muhammed b. Abdullah b. Muhammed b. İbrahim et- Tancî el- Levâtî"dir (Çevik, 2019: 19). İbn Battûta hakkındaki kaynaklar onun Berberî kabilelerinden birisi olan Levatalara mensup olduğunu ve 1304'te Tanca'da doğduğunu söylemektedirler (Parmaksızoğlu, 1999: VII; Çevik, 2019: 19) ${ }^{3}$. Yine kaynaklara göre yapmış olduğu hac seyahati ile kendisinde dünyayı gezmek arzusu doğmuş ve bu arzusunu Ön Asya, Anadolu, İstanbul, Bulgar İli, Kıpçak, Harezm, Horasan, Maverâünnehir, Afganistan, Hindistan, Çin, Fas, Sudan, Mali, Nijerya, Timbuktu, Somali ve Endülüs'ü gezmek suretiyle gerçekleştirmiştir. Onun bu seyahatleri 29 yıl sürmüştür.

Battûta gittiği her yerde insanlarla çabuk kaynaşmış; onlar tarafından saygı görmüştür: "Türkler'in, Moğollar'ın Maldivliler'in hükümdarlarıyla tanışan İbn Battûta birçok ülkede kadılık makamına getirilmiş, Farsça ve Türkçeyi bilmesi ve yolculuklarında çeşitli siyasî tecrübeler kazanması dolayısıla kendisine bazı diplomatik görevler verilmiştir. Derviş gibi giyinmesi ve dervişçe davranması sebebiyle da halk ve ulemâ tarafından seviliyordu." (Aykut, 1999: 361).

İbn Battûta 1353 yılında kırk dokuz yaşındayken seyahatlerini tamamlamış ve 1369

\footnotetext{
2 Seyyahın ismi Türkçe yayınlarda farklı yazılmaktadır: Batuta (Parmaksızoğlu, 1999); Battûta (Aykut, 2004); Batuta (Çevik 2019). Biz Aykut'un imlasını tercih ettik.

317 Recep 703 (25 Şubat 1304 (Aykut, 2004: XXI).
} 
(770) yılında ölmüştür ${ }^{4}$ (Çevik, 2019: 20). Bu sırada Tâmesna-Merrâkeş kadısı idi (Aykut, 2004: XXI).

\section{Seyahatname (Rihle)}

İbn Battûta'nın eserinin asıl ismi Tuhfetu'n-Nuzzâr fî Garâibi'l- emsâr ve Acâibi'lesfâr'dır ${ }^{5}$ (Çevik 2019: 19). Seyahatname, Beni Merin hükümdarlarından intisap ettiği Ebu İnan Fâris'in arzusu üzerine Muhammed İbn Cüzey el-Kelbî tarafından kaleme alınmıștır (Parmaksızoğlu, 1999: IX). İbn Cüzey esere kendisinden de eklemeler yapmıştır. Bu eklemeler daha çok hikâye ve şiir kıtalarından oluşmaktadır (Çevik, 2019: 20). Bu eklemelerdeki kimi tutarsızlıklar esere olan güveni zedelemiştir (Parmaksızoğlu, 1999: IV). Seyahatname'nin İbn Cüzey el-Kelbî tarafından yazılması 1355 (756) yılında bitirilmiştir (Parmaksızoğlu, 1999: XII; Çevik 2019: 22). Bu nüsha günümüze kadar gelmiştir (Çevik, 2019: 22).

"Eser, Avrupalı seyyah ve müsteşriklerin ilgisini çekmiş, Batı dillerine çevirileri yapılmıştır. Seyahatnamede Hindistan ve Afrika'nın zenginliği ile ilgili anlatılanlar, Batılıları eseri daha detaylı incelemeye itmiş ve eser, onlar tarafından sömürgecilik faaliyetlerinde bir rehber gibi görülmüştür. 18. ve 19. yüzyıllarda İç Batı Afrika'da sömürgeciliğin yol açtığı keşiflere kadar bölge hakkındaki en doğru ve detaylı bilgiler İbn Battûta'nın Seyahatnamesinde yer almıştır. O, bu bölgenin esas kâşifi olarak gösterilmiştir." (Ersöz, 2021: 175)

Seyahatname Türkçede ilk olarak muhtasar bir şekilde Süleyman Efendi Matbaası'nda H. 1290 tarihinde basılmıştır (Parmaksızoğlu, 1999: XIII). Bir sonraki baskı Damat Mehmet Şerif Paşa tarafından H. 1325 yılında İstanbul'da yapılmıştır (Çevik, 2019: 22).

Eserin seçme bir yayını İsmet Parmaksızoğlu tarafından İbn Batuta Seyahatnâmesi'nden Seçmeler adıyla Kültür Bakanlığı'nın 1000 Temel Eser serisi arasında çıkmıştır (Parmaksızoğlu, 1999). Bu seçme metinde Anadolu, Kuzey Türk İlleri ve Güneydoğu Anadolu yer almıştır. Eserin tam metin olarak yayını Dr. Mümin Çevik tarafından Íbn Battûta Seyahatnamesi adıyla Bilge Kültür-Sanat Yayınları arasında yayımlanmıştır (Çevik, 2019). Eserin tam metninin yanı sıra notlarla birlikte bir başka yayını ise A. Sait Aykut'a aittir. Bu yayın İbn Battûta Seyahatnâmesi adıyla iki cilt olarak Yapı Kredi Yayınları arasında çıkmıştir (Aykut, 2004).

Konumuzla ilgili olarak Burhanettin Bürol tarafından hazırlanmış "íbn Batuta'ya Göre Deşt-i Kıpçak" adlı teze ise YÖK Tez Kataloğunda rastlayamadık.

\section{3. İbn Battûta ve Deşt-i Kıpçak / Uzbek Han'ın Ülkesi}

Battûta Anadolu seyahatinin ardından Kırım üzerinden Altınordu Devleti'ne gitmek üzere Sinop limanından bir Rum gemisiyle Kırım'a açılmıștır. Böylece Altınordu Devleti'ne geçmiş olan Battûta'nın seyahat ettiği dönemde ise Altınordu Devleti'nde Özbek Han hükmediyordu. Battûta'nın dünyanın en büyük yedi hükümdarından birisi dediği Özbek Han (1313-1340) zamanında Altınordu Devleti altın çağını yaşamıştır (Kafalı, 2007: 109; Ke-

\footnotetext{
41368 (Aykut, 2004: XXI).

${ }^{5}$ Bu çalışmada Aykut neşri tercih edilmiştir. Sayfa numaraları bu yayına aittir.

${ }^{6}$ Eser üzerinde yapılmış başlıca yerli ve yabancı çalışmalar için bu çalışmanın kaynakçasına bkz. (Aykut, 2004: XL-LIII).
} 
maloğlu, 2016: 121).

Battûta, Özbek Han için övgü dolu sözcükler kullanmıştır: "Adı Muhammed Uzbek'tir. Han onların dilinde hükümdar, sultan anlamındadır. Onun geniş bir ülkesi, kuvvetli bir ordusu, şanlı şöhretli bir devleti vardır. O, Tanrı düşmanı Kustantîniye halkıyla cihat etmekte, onları kahretmektedir. Onun ülkesi çok büyüktür, muazzam şehirlerle donanmıştır. Kefâ [= Kefe], Kırem, Macar, Azâk [=Azak], Surdak [=Suğdak], Huvârezm ile taht şehri olan Sarâ [=Saray] bu beldelerin en ünlüleridir. Muhammed Uzbek Han dünyanın yedi ulu hükümdarindan biridir." (474)

Battûta, Sultan'ın yolculuk sırasındaki teşrifatını da anlatır: "Sultan Uzbek bir yere gitmek isteyince beraberinde sadece devlet erkânı ile kapıkulları yer alır. Kadınların her biri ayrı bir halayık tayfasıyla yolculuk yapar. Sultan bunlardan birinin yanına gitmeyi arzularsa teşrif edeceğini önceden haber verir. Hatun ona göre hazırlılarda bulunarak hükümdarı karşılamak üzere bekler. Sultanın seyahati, bir menzilde konaklaması, herhangi bir işe koyulması; bunların hepsi kendine özgü âdetler içinde cereyan eder. (474)

"Sultan tören esnasında bu tahta oturunca sağ yanında Taytuğli Hatun oturur. Onun yanında Kebek Hatun bulunur. Sol tarafta da sirasıly Beyelûn [=Blûn]Hatun ve Urducâ [=Orducî] Hatun otururlar. Tahtın sağ alt kenarında hükümdarın oğlu Tîn Bek, solunda ise öteki oğlu Cânî Bek ayakta beklerler. Ön tarafta sultanın kızı İt Kücücük [= It Küçücük] oturur. Bu kadınlardan biri içeri girince sultan ayağa kalkar, onun elinde tutar, tahta kadar götürüp yerine oturtur. Ama Taytuğlî Hatun teșrif ettikte; "melike" [=baş, kraliçe] olduğu ve en beğenilen hatun olma niteliğini kazandığı için sultan onu köșkün ta kapısında karşılar. Oracıkta elinde tutarak içeriye getirir. Tahtın bulunduğu yere kadar onunla yavaş yavaş ilerler, kibarca yerine oturtur ve kendi makamına geçip kurulur. Kadınların hiçbiri kaç-göç yapmadıkları için bu tören halkın önünde cereyan eder." (475)

"İkindi namazı kılındıktan önce başhatun kalkar. Kumaları, otağına kadar, ona refakat ederler. Başhatun kendi çadırına girinceye dek orada beklerler. Sonra her biri kendi arabastna binerek kaldığı çadıra yönelir. Her hatun yanında elli kadar atlı cariye bulunur. Arabaların önünde yirmi civarında yaşlı kadın yer alır. Onlar da ata binmektedirler. Bunlar "fityân" denilen yiğit hizmetkârlar ile araba arasındadırlar. Hepsinin arkasında yüz kadar genç köle bulunur. Fityân denilen hizmetkârların önünde yüze yakın yüksek rütbeli kapıkulu bulunur. Onlar da ata binmişlerdir. Yüz kadar da yaya köle vardır. Yayalar bellerinde kılıç, ellerinde değnek, atlılarla genç hizmetkârlar arasında yer alırlar. Bütün hatunların geliş ve dönüş tertipleri böyledir." (475)

\section{Kıpçak Ülkesinde Kadınlara Gösterilen Saygı}

Battûta, eserinde: "Bu yörede gördüğüm ilginç tutumlardan birisi de erkeklerin kadınlara gösterdikleri aşırı saygıdır. Bu memlekette kadınlar erkeklerden üstün sayılıyor!” diyerek şaşkınlıkla bunu eserine kaydediyor (472).

Battûta, esnaf ve satıcı eşlerinin toplumda büyük bir şatafata sahip olup; büyük bir saygı gördüklerini de söylemektedir: "Pazar esnafının ve satıcıların eşlerine gelince, bunların durumu diğerlerinden aşağı değil! Onlardan birini atların çektiği muhteşem bir arabada gördüm. Yanında eteklerini tutan üç dört cariye vardı; başında mücevherlerle donatılmış, ön tarafında tavus tüyünden bir sorgucu bulunan ve buğtak adı verilen bir hotoz vardı. Araba- 
nın pencereleri açık olduğu gibi kadının yüzü de örtülmemişti. Zira Türk kadınları yüzleri açık dolaşırlar. Bir başka kadını da aynı şekilde gördüm. Yanındaki köleleriyle pazara süt, yoğurt getirip satıyor, karşılığında esans satın alıyordu." (472)

Dışarıda kadınlar erkeklerden öylesine gösterişlidir ki Battûta, bu durumu kendi hayretiyle birlikte şöyle anlatmaktadır: "Öyle olur ki bazen kadınlara erkekleriyle beraber rastlarsınız da "Şu adam bu hatunun hizmetkârı olmalı!" dersiniz. Zira kocası, koyun postundan bir kürk ile başında da buna uygun "külâ" [= külâh] denilen şapkadan başka bir şey taşımamaktadır!" (475)

Kadınların eserde konu edinilmesinin diğer bir sebebi de dinî kimlikli şahıslara aşırı saygı göstermeleridir: "Bu ülkede halk dervişlere çok yakınlık gösteriyor. Herkes at, öküz, koyun ne bulursa tekkeye gönderiyor; sultan ve hatunları da ahaliden geri kalmiyor. Bereketlenmek için şeyhleri sik sık ziyaret ediyor, ihsanlar yağdırıyor, hediyeler takdim ediyorlar. Hele hele kadınlar bu konuda aşırı bir tutum içindeler!” (471)

Battûta, kadınların bindiği arabaları da tasvir etmiştir: "Kadınların bindikleri arabaların bir köșesine bir arşın boyunda ince bir değnek asıllyor. Ucuna da bir karış uzunlukta keçe parçası bağlanıyor ve her bin at için tek parça bağlıyorlar!” (471)

\section{Hükümdarın Eşleri ve Teşrifat Düzeni}

Battûta, eserinde hükümdarın eşlerinden her birisiyle ayrı ayrı görüşmüş; onlar hakkında teferruatlı bilgiler vermiştir. Öncelikle onların mevki ve düzenleri hakkında şu bilgileri vermiştir: "Her hatun bir arabaya biner. Hatunun araba içindeki odasl, altın havası veren gümüşten veya mücevheratla bezeli ahșaptan mamul bir kubbedir. Arabayı çeken atlar, sırmalı ipekten mamul perdelerle örtülüdür. Koşî [= Koş̧̧i] denilen genç sürücü atlardan birinin üstüne binerek arabayı sürer. Hatun arabada yerine oturduğu vakit, veziri gibi olan kocamış bir kadını sağ tarafına alır. Bu kadına "Ulû Hatun" denilir. Yine yaşlı olup teşrifatçılık ve perdedarlı yapan "Küçük Hatun"u sol tarafina oturtur. Ön tarafta zarafet ve güzellikte eşsiz altı cariye vardır. Onlara benât[=kızlar] deniliyor. Arkada da bu kızlardan ikisi durur; hatun onlara dayanır ve başına buğtak denilen, mücevherle bezeli küçük bir hotoz takar. Bunun üzerine tavus tüyünden bir sorguç kondurur. Sirtında Rum prenseslerinin giydikleri tarzda inciyle bezenmiş "minut"a [= manto] benzer bir elbise vardır. Ulu ve küçük hatunların başlarında da kenarları inci ve altınla işlenmiş yazmalar vardır. Kızlara gelince; "külâ" [ = külâh] denilen hotozlar vardır başlarında... Bu başlığın tepesine mücevherle süslü altın bir halkayla tavus tüyünden sorguçlar takılmıștır. Her birinin elbisesi "nah" adı verilen bir ipek cinsinden mamuldür.

Hatunun önünde Hint asıllı on on beș hizmetkâr bulunur. Bunlar da altın ve mücevher işlemeli ipek elbise giyerler, yanlarında altın yahut gümüşle kaplı değnekler bulunur. Hatunun bindiği arabanın arkasında yüz kadar araba ilerlemektedir; her birinde küçüklü büyüklü üç dört cariye vardır. Bunlar da aynı șekilde ipek elbise ve külâhlarıyla alaya katılmışlardır. Onarın ardında deve yahut öküzlerle çekilen üç yüz kadar arabada ise hatunun hazinesi, süs essyası, elbiseleri ve yiyecekleri taşınmaktadır. Her araba demin bahsettiğimiz cariyelerden biriyle evlendirilmiş bulunan bir genç kölenin zimmetindedir. Çünkü böyle bir evlilik yapmamış kölelerin cariyelere yaklaşmaları; onların işlerini görmeleri yasaktır! Hatunların düzenleri böyledir işte..." (476-477) 
Battûta hükümdarın dört hatunu için yaptığı tasvirler şöyledir:

A. Büyük Hatun: Büyük hatun Hükümdarın has hatunu olması sebebiyle "melike" olarak anılmaktadır. Melikenin diğer hatunlardan bir ayrıcalığı ise; Sultanın kendisinden daha fazla hoşlanması ve saygı göstermesidir. Öyle ki Sultan, gecelerinin çoğunu onun yanında geçirmektedir. Sultan her yanına vardığında onu adeta bakire gibi buluyormuş. Sultanın ona olan bu ilgisinden dolayı halk da ona saygı göstermektedir. Bu hatunun Battûta'ya göre bir eksiği fazla cimri olmasıdır.

Battûta, Sultandan sonra bu hatunun huzuruna çlkmıştır. Yazar, bunun sebebini ise: "Sultan nezdinde en klymetli hatun olması" olarak açıklamıştır. Yazar, hatunun çadırını oldukça dikkatli gözlemlemiş ve bunları eserine yansıtmıştır. Buna göre melike on kadar yaşlı hizmetçisi arasında oturmaktadır. Önünde ise sayısının neredeyse elliye yakın olduğu söylediği benât [ = kızlar] şeklinde çağrılan kalabalık bir cariye topluluğu bulunmaktadır.

"Büyük hatun, "melike"dir [= kraliçe]. İleride bahsedeceğimiz Cânî Bek ile Tîn Bek'in anası odur. Sultanın kızı İt Küçücük'ün annesi ise bu kadından önce melikelik yapan Taytuğlî Hatundur. Sultanın en çok hoşlandığı ve saygı gösterdiği kadın odur. Hükümdar gecelerin çoğunu onun yanında geçirir. Halk bu ilgiden ötürü Taytuğlî̀ya fazla saygı gösterse de onun hatunlar arasında en cimri olduğunu herkes bilir! Sultanın, bu kadını "özel bir vasfindan" ötürü sevdiğini söylemiști bana güvenilir bir dostum! Sultan her yaklaştığında onu bakire gibi buluyormuş! Bir başkasının bildirdiğine göre o kadın Hz. Süleyman’ın saltanatının çökmesine sebep olan hatunun soyundan geliyormuș! Süleyman Peygamber yeniden iktidara gelince: "O hatunu tek canlının dahi bulunmadı̆̆ı bir bozkıra atın!" diye emir vermiș. Böylece kadın Kafcak [= Kıpçak] bozkırına bırakılmış. O kadının rahmi halka şeklinde yaratılmış; onun neslinden gelenler de öyleymiş! Gerçi Deşt-i Kıpçak yöresinin dışında, her hangi bir kadının rahminin böyle yaratıldığına dair ne bir söylenti duydum ne de gören veya duyanla karşılaştım. Allah biliyor ya sadece Çin'de böyle kadınların bulunduğunu bir Çinli söylemişti bana. Elime böylesi geçmedi, yalan yok! işin hakikatini de bilmem...

Sultanla görüşmemizden bir gün sonra bu hatunun huzuruna çıtım; çocuk yapma zamanı geçmiş on kadar yaşlı hizmetçi arasında oturuyor, önünde neredeyse elli cariye bulunuyordu. Benât [= kızlar] diye çağırılan bu cariyeler altın ve gümüş tabaklara konmuş kirazları ayıklıyorlardı. Hatun da önündeki altın siniden bir şeyler ayıklıyordu. Ona selâm verdik. Bizim grupta Mısır usûlu Kur'an okuyan bir hafız vardı, tatlı sesiyle bir aşır okudu. Büyük hatun derhal "kımız" servisi yapılmasını emretti, bizzat kendi eliyle oradaki süslü tahta kadehlerden biriyle kımız sundu bana! Onlar bu hareketi en yüksek taltif olarak görürler. Ben evvelce kımız içmemiştim ama kabul etmekten başka çare de yoktu! Nitekim tattım ve hiç beğenmedim! Yanımdaki arkadaşlardan birine uzattım. Büyük hatun yolculuğumuzla alâkalı epey soru sordu, biz de etraflı cevaplar verdik.

Sonra huzurundan çıktık; sultan nezdinde en klymetli hatun oydu, bu yüzden ziyaretlere ondan başlamıștık." [477-478)

\section{B. Büyük Hatunu Takip Eden İkinci Hatun:}

Batuta, hatunun adının Kebek olduğunu ve bu adın da "Türkçede ayıklanan şey, kepek" anlamında olduğunu yazması onun ne derece dikkatli veri topladığını ve okuyucularına karşı onları bilgilendirmede nasıl özverili olarak çalıştığını da göstermektedir. 
Kebek'in maiyetini de İbn-i Batuta şu şekilde vermiştir: yanında yaşlı kadınlardan on; kızlardan da gergef işleyen yirmi cariye bulunmaktadır. Kebek de yazara eliyle kadeh sunacak kadar nezaket ve tevazu sahibidir.

"Adı Kebek Hatun'dur. "Kebek" Türkçede ayıklanan şey; kepek anlamına gelir. Babasının ismi Nagatay'dır. Nagatay'ın hâlen sağ olduğunu fakat "nıkris" [= damla] hastalığından mustarip bulunduğunu öğrendik. Büyüğü ziyaretimizden bir gün sonra Kebek Hatun'a vardık. Huzuruna girdiğimiz vakit bir döşek üzerine oturmuş Kur'an okuyordu; yanında yaşlı kadınlardan on, kızlardan da gergef işleyen yirmi cariye vardı. Onu selâmladığımızda bize daha kibar ve güzel bir karşılık verdi. Hafızımız hemen Kur'an okudu; Kebek Hatun memnun oldu ve kımız getirilmesini emretti. O da kraliçe gibi kadehi bana kendi eliyle sundu. Onun yanından da ayrıldık." (478)

\section{C. Üçüncü Hatun:}

Sultanın üçüncü hatunu Rûm hükümdarının kızıdır. Bu hatunun etrafında daha çok aynı bölgeden Rûm, Türk ve Nûba ırkından yüz kadar cariye kendisine hizmet etmektedir. Battûta, Bizans'ın merkezi İstanbul'u ziyareti sırasında bu hatunun yardımlarını görmüştür.

“İsmi Beyelûn'dur. Büyük Kustantîye hükümdarı Tekfûr'un kızıdır. Huzuruna girdiğimizde gümüş ayaklı, altın bezeli tahtında oturuyordu; Rum, Türk ve Nûba ırkından yüz kadar cariye de önünde bekliyordu. Bunları kimi çömelmekte, kimi ayakta dikilmekteydi. Genç hizmetkârlar, hatunun başucunda bekleşmekteydiler. Onun perdedarları [=teşrifatçılar] Rumlardandl.

Hâl hatır sordu; oraya ne zaman geldiğimiz, vatanlarımızın ne denli uzak olduğu vs. sualler yöneltti. Şefkatli ve yumuşak kalpli idi; hemen ağladı ve elindeki mendille gözyaşlarını sildi. Yemek hazırlatılmasını emretti. Sofra kurulunca onun huzurunda yedik; bizi seyrediyordu.

Ayrılmak istediğimiz zaman şöyle dedi: "Bizimle alâkanızı kesmeyiniz! Tekrar uğrayınız yanımıza ve herhangi bir șeye ihtiyaç duyarsanız hemen bize bildiriniz!" böylece cömertliğini, erdemini göstermiş oldu. Arkamızdan [bir öğünlük hazır] yemekle birlikte ekmek, yă̆, koyun, para, yepyeni elbiseler ve üçü asil cinsten tam on üç at yolladı. İstanbul seyahatimiz aşağıda anlatacağım gibi bu hatunun himayesinde olmuştur." (478-479)

\section{Dördüncü Hatun:}

Hatunun ismi Urducâ'dır. Karargâhta doğduğu için kendisine bu isim verilmiş. İbn-i Battûta'ya göre Sultan'ın eşleri içerisinde: "simaca en tatlı, huyca en merhametli ve erdemli olandır."

"Onun ismi Urducâ'dır. "Urdû" [= ordu] onların dilinde karagâh demektir. Karargâhta doğduğu için bu ad verilmiş ona. Bu kadın "ulus" [=ulus; büyük kabile] başı Emir İsa'nın kızıdır. Biz geldiğimizde İsa sağdı ve sultanın kızı İt Küçücük'ün kocasıydı.

Urducâ hükümdar eşleri arasında simaca en tatll, huyca en merhametli ve erdemli olandır. Daha önce de açıkladı̆̆ımız gibi, ordu yerine ulaştığımız vakit beni tepede çadırın önünde görünce adam gönderip hâlimi hatırımı soran ilk soran da bu kadındır. Huzuruna geldiğimiz vakit yüksek mizacına, iyiliksever ruhuna bir kez daha tanık olduk. Bize yemek 
çıkarttı. Huzurunda yedik içtik, kımız sundu, yoldaşlarımız aldılar; [biz almayınca] durumumuzu anlamak istedi; gereken izahatı verdik. Onun yanından ayrıldıktan sonra Emir Ali $b$. Erzak'la [= Erzen] evli olan kız kardeșini de ziyaret ettik." (479)

Battûta, eserinin bir yerinde daha bu hatundan bahseder: "Sultanın hanımlarının her biri, kendi çadır [=otağ] malzemeleri ile önümüzden geçti. Bu hanımlarının dördüncüsü İsa Bey'in kızlydı; yolda ilerlerken tepe üzerinde bir yabancının geldiğini belirten bayraklı çadırı görmüş, yanımıza cariyelerini göndermişti. Onlar geldiler, bizi selâmladılar ve hatunun selâmını bildirdiler. Hatun ise aşağıda, yolda bekliyordu; ona Tülük Tümür'un teşrifatçısıbaşısı olan adamla hediye gönderdim, bir arkadaşım eşliğinde. Lütfederek hediyelerimi kabul etti. Benim, kendi çadırı civarına kondurulmamı emir buyurarak arabacısına hareket işareti verdi. Onun ardından sultan geldi. O da kendisi için ayrılan otağa doğru gitti." (474)

\section{E. Sultanın Kızı İt Küçücük Hatun:}

Battûta, Sultan'ın eșlerinin yanı sıra kızlarından İt Küçücük Hatunu da ziyaret etmiş ve eserinde ondan da sitayişle bahsetmiştir. İbn Battûta misafir olduğu bu kızdan gördüğü misafirperverlikten ziyadesiyle memnun kalmış ve ondan: "cömerdlik ve erdem bakımından bir benzerini görmediğim kadındır. Hak Teâlâ ona en güzel mükâfatı versin." șeklinde bahsetmektedir.

Battûta'nın gözlemlerine göre her bir çadırda her bir hatun kalabalık maiyetiyle birlikte bulunmaktadır. Çadırın içi oldukça coşkun bir kalabalık barındırmaktadır.

"Adı İt Küçücük'tür. Adının karşılığı "Kelb-i Sağı̂r"dir. Çünkü it'in Arapçası kelb, "küçücük"ün Arapçası ise sağîrdir. Daha önce de belirtmiştik; Türkler aynı Araplar gibi fal ile isim veriyorlar. Babasının otağından altı mil uzaklıkta kendine ait bir yerde oturan bu hatuna yöneldik. Bizim ziyaretimizde hazır bulunmaları için kadıya, fakihlere, Seyyid Şerif b. Abdülhamîd'e ve onun öğrencilerine emir verdi; nihayet kocasıİsa da geldi. İsa'nın kızı sultanın eşidir. It Küçücük Hatunla aynı sedire oturdu. Bu adam damla [= nıkris] hastalığı çektiği için ne ata binebiliyor ne de yürüyebiliyor. Hükümdarın huzuruna çıkması gerektiği vakit hizmetkârları onu arabadan indirip koltuğuna girerek taşıyorlar. İkinci hatunun babası Nagatay Bey'i de aynı hastalıktan mustarip buldum. Bu meret, Türkler arasında çok yaygın! Sultanın kızı It Küçücük Hatun, cömertlik ve erdem bakımından bir benzerini görmediğim kadındır. Hak Teâlâ ona en güzel mükâfatı versin." (480).

\section{Sonuç}

İbn Battûta XIV. yüzyılın en önemli seyyahlarındandır. O, döneminin pek çok önemli kültür merkezine seyahatlerde bulunmuş; gezdiği yerleri dikkatle gözlemlemiş ve bu yörelerin sosyal yaşantısından ilginç anekdotlar aktarmıştır.

Battûta'nın gezdiği yerlerden birisi de Deşt-i Kıpçak olarak adlandırılmış Altınordu Devleti'dir. Battûta'nın seyahati esnasında devletin başında Özbek Han bulunuyordu. Battûta hem hükümdar hem de eşleri tarafından büyük saygı görmüş; her birisi tarafından ayrı ayrı kabul edilmiștir.

Battûta'nın Altınordu Devleti'nde gördügü ve hayran kaldığı durumda bu toplumda kadınların görmüş olduğu saygıdır. Öyle ki Battûta eserinde bu saygının benzerini hiçbir yerde görmediği itirafında da bulunmaktadır. 0 , bu saygıyı ifade ederken: "Burada kadın- 
lar erkeklerden daha fazla saygı görüyor." ya da "Kadının yanındaki eși kölesi gibi görünüyor." gibi ifadeleriyle toplumdaki kadına gösterilmiş olan saygının derecesini net olarak tasvir etmektedir.

Eski Türk tarihinde kadınlara gösterilmiş saygının bir benzerinin uzantısına XIV. yüzyılda Altınordu Devleti'nde rastlanılmaktadır. Burada kadınların sosyal yaşantıdan ötelenmediği, baş tacı edildiği ve erkeklerden daha üstün tutulduğu Battûta'nın eseri ile belgelenmiş olmaktadır.

Döneminin en güçlü ve en zengin ülkelerinden birisi durumundaki Altınordu Devleti aynı zamanda kadına gösterilen saygıyla da döneminin en medenî ülkelerinden birisi durumundadır. Bu haliyle XIV. yüzyılda eski Türk kültürünün bir uzantısı görünümündedir.

Battûta'nın Seyahatnamesi 14. Yüzyıl Türk dünyasını anlamada bir rehber görevini görmektedir. Anadolu'dan Kıpçak'a, Kıpçak'tan Harezm'e 14. Yüzyıl Türk coğrafyasında sosyal hayatın canlı tasvirlerle anlatıldığı bu eser Türk kültür tarihi araștırmalarında büyük bir öneme sahiptir.

\section{Kaynaklar}

Aykut, A. S. (1999). “İbn Battûta”. İslâm Ansiklopedisi. 19 c. 361-368 s. İstanbul: Türkiye Diyanet Vakfı Yayınları.

(2004). Ebû Abdullah Muhammed İbn Battûta Tancî. İbn Batûta Seyahatnâmesi I - II. İstanbul: Yapı Kredi Yayınları.

Çevik, M. (2019). Ebu Abdullah Muhammed İbn Battûta et-Tancî. İbn Battûta Seyahatnamesi. İstanbul: Bilge-Kültür Sanat Yayınları.

Ersöz, Ș. N. (2021). "İbn Battûta”. İslam Medeniyetinde Bilim Öncüleri-2. Coğrafya. İstanbul: Mana Yayınları.

Kafalı, M. (2007). “Özbek Han”. İslâm Ansiklopedisi. 34 c. 107-109 s. İstanbul: Türkiye Diyanet Vakfı Yayınları.

Kemaloğlu, İ. (2016). "Altın Orda Devleti”. Avrasya'nın Sekiz Asrı Çengizoğulları. İstanbul: Ötüken Yayınları.

Parmaksızoğlu, İ. (1999). İbn Batuta Seyahatnâmesi'nden Seçmeler. Ankara: Kültür Bakanlığı Yayınları. 